\title{
Pinworm (Enterobius vermicularis) Infection among Primary Level Government School Children of Chhampi, Lalitpur District, Nepal
}

\author{
Karuna Khadka and Mahendra Maharjan* \\ Central Department of Zoology, Tribhuvan University, Kirtipur, Kathmandu, Nepal.
}

Abstract: Introduction: Poor sanitation and crowding effect are easy way for transmission of enterobiasis between infected and uninfected person and it is usually common among playgroup and school kids.

Subject and Methods: Among the various health problem of school children, enterobiasis is one of them still present among the school children in context of Nepal. Unawareness along with unhygienic lifestyle as well as crowdy environment may be the major reasons behind this. This study was aimed to find enterobiasis of school children in Chhampi, Lalitpur. The students were categorized on basis of age, sex, ethnic group, itching habit, nail biting habit and playing with domestic pets habit. A total of 107 cellophane samples of 2-13 years aged children were included for the microscopic examination.

Result: Overall 11(10.28\%) enterobiasis prevalence were reported in children including 10.91\% male and 9.26\% female. Age group 5-7 years was found to be highly infected (4.67\%). There was absence of enterobiasis among the age group 11-13 years. There was insignificant statistics association ethnically with the enterobiasis however the prevalence rate was higher in Janajati (54.54\%). There were no significant association between pinworm infection with scratching habit around anus $(\mathrm{P}>0.05)$ and nail biting habit $(\mathrm{P}>0.05)$ of children.

Conclusion: The prevalence was found to be high among primary level children and Scotch tape was a specific test for the detection of eggs of pinworm against enterobiasis.

Keywords: Cellophane, Chhampi, Children, Enterobiasis, Nail biting, Prevalence, Swabbing.

\section{INTRODUCTION}

Pinworm (Enterobius vermicularis), is a common nematode parasite among children. Although pinworm infection (enterobiasis) is not commonly serious but usually common parasitic infection [1]. The disease is typical of cosmopolitan communities, particularly those with a high concentration of infants, is found predominantly in the low or social classes with a poor socio-economic and hygiene level [2]. 200 million people are globally infected by enterobiasis [3]. Infectious nature of enterobiasis makes it more transmissible among crowded environment specially in joint families and educational organizations [4].

The pinworms are attach to mucosal layer and usually live in the cecal region, vermiform appendix and distal intestine. Scratching around the anus is the major symptom of this disease [5]. In addition to this, unease, anxiety, sleeplessness and stomachache are also seen [6]. The principle mode of transmission of E. vermicularis is direct contact between infected and uninfected persons [7].

In children, nervousness, insomnia, nightmares and even convulsion have been attributed to enterobiasis [8]. Continual scratching by the patients to the perianal area may injure skin

*Address correspondence to this author at the Central Department of Zoology, Tribhuvan University, Kirtipur, Kathmandu, Nepal.

E-mail: mmaharjan@cdztu.edu.np and cause secondary bacterial infections [9]. Although this disease is non-injurious, egg deposition of pinworm can cause perneal and vaginal itching [10]. Loss of weight, pain in urination and appendicitis can be seen in rare and serious cases $[11,12]$. Around only $5 \%$ of E. vermicularis eggs can be detected in stool [13]. Swabbing is the method to be carried at night or early morning for the egg detection before bathing or defecation [4]. Cellophane tape is the effective procedure of definite diagnosis for almost $100 \%$ positive cases [14]. Continuous monitoring of infection rates is key to successful disease control [15].

\section{MATERIAL AND METHODS}

\section{Study Area}

The present study was carried out among 107 primary school children aged between 2-13 of Shree Chhampi Devi Higher Secondary School in Chhampi, Lalitpur District over period of seven months, from April to October.

\section{Collection of Anal Swabs}

This study included representing more than $50 \%$ of total primary level children of the school who wished to participate in the present study. Authorization was taken from head teacher of school, parents and head of health post for conduction of research. Three parents and teachers meeting were conducted in the school to explain the aim and objectives 
of the study. The parents were well explained about the methods of the sample collection.

Scotch tape samples collection was used. The identification tag was used at one end of glass slide. For the detail collection of data, a record file was used with name, age and sex. Parents were detail informed by the process of swabbing and they were also shown the attachment of cellophane around the perianal region of their child. Parents were requested to return the samples of cellophane tape next morning.

\section{Questionnaire Survey}

A pre-tested self-administrated questionnaire was used to collect the information regarding behaviours of children including itching habit, nail biting habit and playing habit with domestic pets.

\section{Data Analysis and Interpretation}

The obtained data were managed and analyzed according to age, sex, ethnic group, behaviors of children and rate of intensity. Fisher's exact test at $95 \%$ confidence interval was used for determination of significant association. The software used for this analysis was "R" software version 3.4.1.

\section{RESULTS}

Out of 107(55 male and 52 female) children examined, $10.28 \%$ were found to be positive for $E$. vermicularis infection. E. vermicularis infection was found to be $10.91 \%$ and $9.26 \%$ in male and female respectively (Table 1). No significant association was reported with sex $(\mathrm{P}>0.05)$. While age wise prevalence indicated high among children between age group 5-7yrs (Table 1) but absence of positive result for age group 11-13 and no significant association of age with enterobiasis $(\mathrm{P}>0.05)$.

Table 1. Enterobiasis among Primary Level Children Chhampi, Lalitpur.

\begin{tabular}{|c|c|c|c|}
\hline $\begin{array}{c}\text { Age } \\
\text { Groups }\end{array}$ & $\begin{array}{c}\text { Male } \\
\text { Examined }\end{array}$ & $\begin{array}{c}\text { Female } \\
\text { Examined }\end{array}$ & $\begin{array}{c}\text { Total Examined } \\
\text { (N= 107) }\end{array}$ \\
\hline $\mathbf{2 - 4}$ & $3.63 \%$ & $1.92 \%$ & $2.80 \%$ \\
\hline $\mathbf{5 - 7}$ & $5.45 \%$ & $3.85 \%$ & $4.67 \%$ \\
\hline $\mathbf{8 - 1 0}$ & $1.82 \%$ & $3.85 \%$ & $2.80 \%$ \\
\hline Total & $10.91 \%$ & $9.62 \%$ & $10.28 \%$ \\
\hline
\end{tabular}

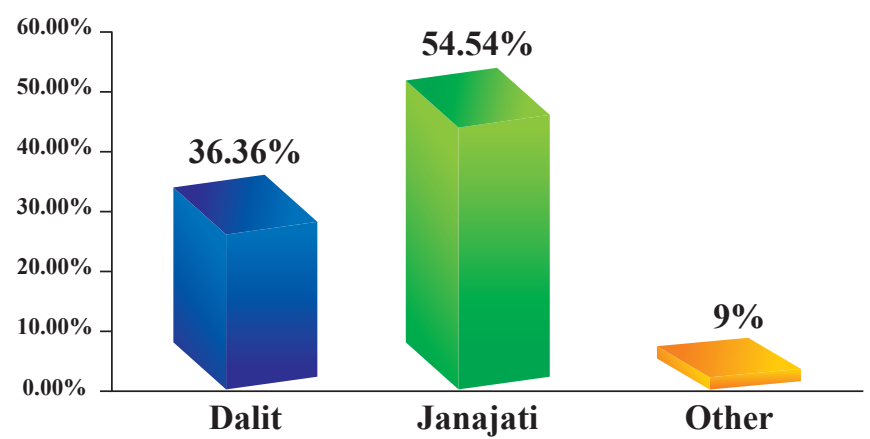

Fig. (1). Prevalence of Enterobius vermicularis with Ethnic Group wise.

Janajati children $(54.54 \%)$ were more infected than other ethnical groups (Fig. 1). Distribution of E. vermicularis to that of ethnic groups was statistically no significant association ( $\mathrm{P}$ $>0.05$ ).

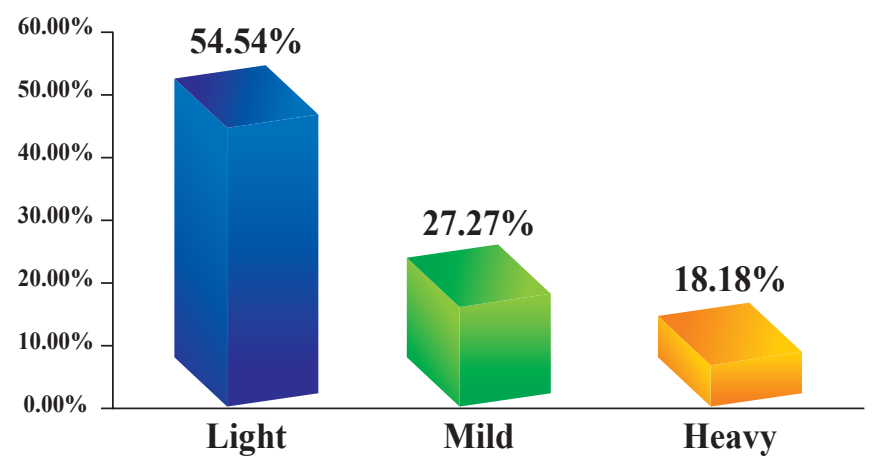

Fig. (2). Intensity of Enterobius vermicularis Infection in Children.

Intensity of infection was classified as light, mild and heavy infection. If there was less than 2 eggs, it was considered as light infection, 2-4 eggs mild and more than 4 eggs was considered as heavy infection. Maximum children had light infection $(54.54 \%)$ compared to mild and heavy infection (Fig. 2).

Table 2. Children's Behavioural Practices in Relation to $E$. vermicularis Infection.

\begin{tabular}{|c|c|c|c|}
\hline Behaviours & Practices & Infection & P value \\
\hline \multirow{2}{*}{$\begin{array}{c}\text { Itching } \\
\text { habit }\end{array}$} & Yes & $9(81.81 \%)$ & \multirow{2}{*}{$>0.05$} \\
\hline & No & $2(18.18 \%)$ & \\
\hline \multirow{3}{*}{$\begin{array}{l}\text { Nail biting } \\
\text { habit }\end{array}$} & No & $2(18.18 \%)$ & \multirow{3}{*}{$>0.05$} \\
\hline & Sometimes & $6(54.54 \%)$ & \\
\hline & Frequently & $3(27.27 \%)$ & \\
\hline \multirow{2}{*}{$\begin{array}{c}\text { Playing } \\
\text { with } \\
\text { domestic } \\
\text { pets }\end{array}$} & Yes & $7(63.63 \%)$ & \multirow{2}{*}{$>0.05$} \\
\hline & No & $4(36.36 \%)$ & \\
\hline
\end{tabular}


Itching habit was closely associated with infection rate and was highest $(81.81 \%)$ which was not statistically significant $(\mathrm{P}>0.05)$. Similarly, E. vermicularis infection was not also significantly associated with nail biting habit $(\mathrm{P}>0.05)$. In case of playing behaviour with domestic pets was not found to be significantly associated with $E$. vermicularis infection $(\mathrm{P}>$ 0.05) (Table 2).

\section{DISCUSSION}

Enterobiasis is usually endemic in kindergartens and primary school, due to easy transmission from infected to uninfected children [16]. Out of 107 school children, 10.28\% enterobiasis was observed. This infection rate is similar to the $12.72 \%$ infection in previous finding of Nepal [17]. Similarly, the present finding is also consistent to other previous studies in Korea [18, 19] and China [20].

However, in comparison to other studies in USA [21] and China [20], enterobiasis among children in this study is less. Similarly, very low prevalence i.e $0.4 \%$ from South Italy [22], $0.40 \%$ from Bhaktapur district, Nepal [23] and 5.52\% in Chitwan district, Nepal [24] were reported. Low prevalence among school children may be due to the increase awareness, personal hygiene and deworming programmes in schools.

Comparatively prevalence of $E$. vermicualris was very high in Venezuela i.e. 91.1\%, in USA [25] and Western Europe [21], in Chile 35.2\% [26] and in Sweden 33\% [27]. The high rate of infection in those places may be due to the cultural behaviour, climatic condition, fast growth of population and economic status. The high rate of infection in school aged children than smaller aged children are more likely to be in close contact with each other and are exposed to unsatisfactory sanitary environment.

Sex wise analysis revealed nearly equal prevalence but higher $(10.91 \%)$ in male children compared to female children $(9.62 \%)$ without significant association in prevalence of enterobiasis between two sexes. Similar findings have also reported previously in Turkey [28], in Korea [19], in Nepal [24]. A higher rate of infection in male than the females was reported in Taiwan and Philippines $[13,29]$. The high rate of infection in male may be due to they spend more time outside and have more chance to contact with infected children, thus acquiring infection. Similar rate of infection among both sexes may be due to the reason they both share similar type of environment and feeding habit. However, high prevalence among female compared to male children was reported in Korea [18] and Iran [30].

Regarding to the age groups though there was no significant association in prevalence rate in age groups, the high prevalence rate was found in 5-7yrs $(4.67 \%)$ followed by $8-10$ yrs $(2.80 \%)$ and $2-4(2.80 \%)$ yrs age group children. The absence of prevalence rate among 11-13yrs age group may be due to the hygiene parameters among older age groups. The higher prevalence rate was observed in 5-7 yrs as compared with older ones. The reason behind this might be due to the most exposure of this age groups to out environment, outdoor games and might be contact with contaminated soil and water. The minimum prevalence of enterobiasis among 2-4 yrs age group might be due to the parental care specially by mothers. Similar result have also been reported in Iraq [31], in South Jordan [32], in Philippines [30], in Thailand [33], in Nepal [17].

This study included Dalit, Janajati and others as ethnical groups. Janajati children $(54.54 \%)$ were highly infected with enterobiasis and this might be due to the poor personal hygiene, poor economic status and lack of knowledge in this ethnical group as compared to others.

During the surveillance study, it was found that the prevalence of pinworm with itching habit was statistically insignificant $(\mathrm{P}$ $>0.05)$. The highest prevalence $(81.81 \%)$ was reported among the children with scratching habit around the anus regions compared to non- itching $(18.18 \%)$. The present result was not in agreement with the result of Iran [34] and Nigeria [35] which observed the significant association of enterobiasis with anus itching and Nail biting habits. This study also disagrees with observation in China [20] in which washing before eating, sucking fingers and toys and scratching around the anus, were all associated with enterobiasis. Similary in this study, there was no significant association of enterobiasis and playing with domestic pets, the result disagreed with children infected with intestinal parasites and close proximity to domestic animals or pets [36]

\section{CONCLUSION}

Out of 107 Cello tape samples examined, enterobiasis was $10.28 \%$. The male children were more infected $(10.90 \%)$ by enterobiasis than the female $(9.62 \%)$. In case of sex wise distribution of enterobiasis, higher prevalence rate was found in 5-7 years old age group $(4.67 \%)$ followed by $2-4(2.80 \%)$ and $8-10$ years old age group $(2.80 \%)$. Regarding the ethnical distribution, Janajati children (54.54\%) were infected highly compared to Dalit $(36.36 \%)$ and others $(9 \%)$. Light infection of enterobiasis was found to be higher $(54.54 \%)$ followed by mild $(27.27 \%)$ and heavy infection (18.18\%). In case of behavioural practices of children in relation to $E$. vermicularis infection, itching around the anal region, nail biting habit and playing with domestic were statistically insignificant.

\section{CONFLICT OF INTEREST}

Declared None.

\section{ACKNOWLEDGEMENTS}

We are extremely thankful to Mr. Surath Gautam, principal of Shree Chhampi Devi High School and other teachers for ever 
kind of assistance. We express sincere thanks to all parents of students for their co-operation during the field work. We are greatful to all the staffs of Central Department of Zoology, T.U., Kirtipur, Kathmandu, Nepal for their motivation and support.

\section{REFERENCES}

[1] Cadwell JP. Pinworm (Enterobius vermicularis). Can Fam Physician 1982; 28: 306-9.

[2] Habbari K, Tifnouti A, Bitton G, et al. Geohelminthic infections associated with raw waste water reuse for agricultural purposes in Beni-Mellal, Morocco. Parasitol Int 2000; 48(3): $249-54$.

DOI: $10.1016 / \mathrm{S} 1383-5769(99) 00026-4$

[3] Prevention and Control of Intestinal Parasitic Infections: Report of a WHO Expert Commitee. WHO Technical Report Series: 749. Geneva: World Health Organization 1987.

[4] Brooker S, Bundy DAP. Soil- transmitted helminthes (geohelminths). In: Cook GC, Zumla A, Eds. Manson's Tropical Medicine. 22 $2^{\text {nd }}$ ed. London: Elsevier Health Sciences 2009; pp. 1256-530.

[5] Russell LJ. The pinworm, Enterobius vermicularis. Prim Care 1991; 18(1): 13-24.

[6] Lagasse P, Goldman L, Hobman A. The Columbia Encyclopedia. $6^{\text {th }}$ ed. Colombia: University Press 2008.

[7] Patsantara GG, Piperaki ET, Tzoumaka BC, et al. Immune responses in children infected with the pinworm Enterobius vermicularis in central Greece. J Helminthol 2016; 90(3): 337-41. DOI: 10.1017/S0022149X15000334

[8] Shoup B. Diagnosis and management of pinworm infection. Prim Care Update Ob/Gyms 2001; 8: 240-3.

DOI: $10.1016 / \mathrm{S} 1068-607 \mathrm{X}(01) 00088-9$

[9] Quasem MA, Salam MA. Ectopic enterobiasis: Case report. Pak J Med Sci 2007; 23(5): 785-7.

[10] MacPherson DW. Intestinal parasites in returned travelers. Med Clin North Am 1999; 83: 1053-75.

[11] Saxena AK, Springer A, Tsokas J, et al. Laparoscopic appendectomy in children with Enteriobius vermicularis. Surg Laparosc Endosc Percutan Tech 2001; 11(4): 284-6. DOI: 10.1097/00129689-200108000-00012

[12] Dickson R, Avasihis S, Demellweek C, et al. Antihelmintic drugs for treating worms in children: Effects on growth and cognitive performance. Cochrane Database of Syst Rev 2003.

[13] Chu TB, Liao CW, Nara T, et al. Enterobius vermicularis infection is well controlled among preschool children in nurseries of Taipei city, Taiwan. Rev Soc Bras Med Trop 2012; 45(5): 646-8.
DOI: $10.1590 / \mathrm{S} 0037-86822012000500020$

[14] Lee KJ, Lee IY, Im K. Enterobius vermicularis egg positive rate in a primary school in Chungchongham-do (province) in Korea. Korean J Parasitol 2000; 38(3): 177-8. DOI: $10.3347 / \mathrm{kjp} .2000 .38 .3 .177$

[15] Kang S, Jeon HK, Eom KS, et al. Egg positive rate of Enterobius vermicularis among preschool children in Cheongju, Chungcheongbuk-do, Korea. Korean J Parasitol 2006; 44(3): 247-9. DOI: $10.3347 / \mathrm{kjp} .2006 .44 .3 .247$

[16] Li HM, Zhou CH, Li ZS, et al. Risk factors for Enterobius vermicularis infection in children in Gaozhou, Guangdong, China. Infect Dis of Poverty 2015; 4: 28.

DOI: $10.1186 / \mathrm{s} 40249-015-0058-9$

[17] Dahal T, Maharjan M. Prevalence of Pinworm and other intestinal parasitic infections among the children of Barbhanjyang VDC, Tanahun District, Nepal. J Inst Sci and Tech 2015; 20(2): 18-21. DOI: 10.3126/jist.v20i2.13943

[18] Kim BJ, Lee BY, Chung HK, et al. Egg positive rate of Enterobius vermicularis of primary school children in Geoje island. Korean J Parasitol 2003; 41(1): 75-7.

DOI: $10.3347 / \mathrm{kjp} .2003 .41 .1 .75$

[19] Lee SE, Lee JH, Ju JW, et al. The prevalence of Enterobius vermicularis among the preschool children in Gimhaesi-si, Gyeongsangnam. Korean J Parasitol 2011; 49(2): 183-5. DOI: $10.3347 / \mathrm{kjp} .2011 .49 .2 .183$

[20] Wang S, Yao Z, Hou Y, et al. Prevalence of Enterobius vermcularis among preschool children in Xinxiang city, Henan province, Central China. Parasite 2016; 23(30): 1-5.

[21] Burkhart CN, Burkhart CG. Assessment of frequency, transmission and genitourinang complication of enterobiasis (pinworm). Int J Dermatol 2005; 44(10): 837-40.

DOI: $10.1111 / \mathrm{j} .1365-4632.2004 .02332 . \mathrm{x}$

[22] Gualdieri LL, Rinaldi L, Petrollo ME, et al. The intestinal parasites immigrants in the city of Naple (Southern Italy). Acta Trop 2011; 117(3): 196-201.

DOI: $10.1016 /$ j.actatropica.2010.12.003

[23] Shrestha R, Maharjan M. Assessment of Efficacy of single dose Albendazole treatment of intestinal helminth parasites in school children. Nep J Zoo 2013; 1: 48-59.

[24] Pandit I. Scotch tape Survey on Enterobius vemicularis in Chitwan District Nepal. M.Sc. Thesis. Kathmandu, Nepal: Central Department of Zoology, Tribhuvan University 2004.

[25] Devera R, Perez C, Ramos Y. Enterobiasis in students from Ciudad Bolivar, Venezula. Bol Chil Parasitol 2006; 53(1-2): 14-8.

[26] Mercado R, Otto JP, Perez M. Seasonal variation of intestinal protozoa infections in our patients of the north section of 
Santiago, Chile, 1995-1996. Bol Chil Parasitol 1999; 54: 41-4.

[27] Herrstrom P, Fristrom A, Karlsson A, et al. Enterobius vermicularis and finger sucking in young swedish children. Scand J Prim Health Care 1991; 15(3): 146-8. DOI: $10.3109 / 02813439709018505$

[28] Celiksoz A, Acioz M, Degerli S, et al. Effects of Enterobiasis on primary school children in Sivas, Turkey. Afr J Microbiol Res 2010; 4(8): 634-9.

[29] Cruz MB, Manado CK, Quigao MHR, et al. Detection of Pinworm (Enterobius vermicularis) egg among children aged 3-4 years in Tagumpay, Rizal, using perianal swab method, Philippines. J Arts Sci Comm 2013; 4(2): 57-62.

[30] Nourazian MB, Youssefi MR. Prevalence of Enterobius vermicularis in Babol Medical School, Iran. World Appl Sci J 2011; 19(5): 634-6.

[31] Raza HH, Sami RA. Epidemological study on gastrointestinal parasites among different sexes, occupation and age groups in Sulaimani District, Iraq. The second Kurdistan Conference on Biological Sciences. J Duhok Univ 2009; 12(1): 317-23.

[32] Ammoura AM. The impact of hygienic level on parasite infection to find out the prevalence of intestinal parasites among the primary school children in rural and urban areas in South Jordan. Asian Pac J Trop Med 2010; 3(2): 148-9.

DOI: $10.1016 / \mathrm{S} 1995-7645(10) 60056-9$

[33] Nithikathkul C, Changsap B, Wannapinyosheep S, et al. The prevalence of enterobiasis in children attending Mobile Health Clinic of Hua Chiew Chalermprakiet University. Southest Asian J Med Public Health 2001; 32: 138-42.

[34] Rasti S, Arbabi M, Hooshyar H. High prevalence of Entamoeba histolytica and Enterobius vermicularis among the elderly and mentally retarded in Jundishapur, Iran. J of Microbiol 2012; 5(4): 585-9.

[35] Otu-Bassey IB, Useh MF, Alarible AA. The post treatment effect of enterobiasis on the occurrence of enuresis among the children in Calabar, Nigeria. Asian Pac J Trop Med 2011; 4(4): 315-9. DOI: 10.1016/S1995-7645(11)60093-X

[36] Forson AO, Arthur I, Olu- Taiwa M, et al. Intestinal parasitic infections and risk factors a cross-sectional survey of some school children in a suburb in Accra, Ghana. BMC Res Notes 2017; 10: 485. DOI: 10.1186/s13104-017-2802-7

(C) 2018 National Journal of Health Sciences.

This is an open-access article. 